\title{
PENGARUH IMPOR BAHAN BAKU DAN KOMPLEKSITAS PRODUK TERHADAP PRODUKTIVITAS PERUSAHAAN
}

\section{THE EFFECT OF RAW MATERIAL IMPORTS AND PRODUCT COMPLEXITY ON FIRM PRODUCTIVITY}

\section{Sirma Oktaviani ${ }^{1)}$, Sartika Djamaluddin')}

${ }^{1,2)}$ Departemen IImu Ekonomi, Universitas Indonesia, Jakarta, Indonesia

\begin{tabular}{|c|c|}
\hline ARTICLE INFORMATION & A B S T R A C T \\
\hline & \multirow{11}{*}{$\begin{array}{l}\text { The effect of import liberalization on industrial productivity can occur through } \\
\text { increased access to inputs and technology transfer to imported products. } \\
\text { Another factor that can affect productivity is product complexity. The } \\
\text { calculation results of the } 2010-2014 \text { Product Complexity Index (PCI) based } \\
\text { on the concept of diversity and ubiquity, showed the average } 3 \text {-digit PCI ISIC } \\
\text { was } 0.0946 \text { with a minimum value of }-2.1324 \text { and a maximum of } 2.2157 \text {. This } \\
\text { study aims to look at the effect of imported raw materials on the productivity } \\
\text { of companies that produce more complex products. By using the } 2010-2014 \\
\text { Large and Medium Industry Survey data and involving the firm's fixed effects } \\
\text { and time, empirical results show that imports of raw materials significantly } \\
\text { affect the productivity of companies that produce complex products by - } \\
0.0405 \text {. In addition, it is known that the manufacturing industry takes } \\
\text { approximately one year to absorb technology in complex products so as to } \\
\text { increase firm productivity. Firm-level productivity is calculated based on the } \\
\text { Levinshon-Petrin (2003) estimated productivity to control selection and } \\
\text { simultaneity bias. }\end{array}$} \\
\hline Received: November 09, 2019 & \\
\hline & \\
\hline Accepted: January 10, 2020 & \\
\hline & \\
\hline Keywords: & \\
\hline Import of raw materials & \\
\hline Product Complexity Index & \\
\hline Industry & \\
\hline Total Factor Productivity & \\
\hline & \\
\hline
\end{tabular}

Kata kunci:

Impor bahan baku Indeks Kompleksitas Produk

Industri

Total Faktor Produktivitas

\section{A B S T R A K}

Efek liberalisasi impor terhadap produktivitas industri dapat terjadi melalui peningkatan akses input serta transfer teknologi pada produk impor. Faktor lainnya yang dapat mempengaruhi produktivitas adalah kompleksitas produk. Hasil perhitungan Product Complexity Index (PCI) 2010-2014 berdasarkan konsep keragaman dan ubiquity, menunjukkan rata-rata $\mathrm{PCl}$ ISIC 3 digit adalah 0.0946 dengan nilai minimum -2.1324 dan maksimum 2.2157. Penelitian ini bertujuan untuk melihat pengaruh impor bahan baku terhadap produktivitas perusahaan yang lebih banyak menghasilkan produk kompleks. Dengan menggunakan data Survei Industri Besar dan Sedang tahun 2010-2014 serta melibatkan efek tetap perusahaan dan waktu, hasi empiris menunjukkan impor bahan baku mempengaruhi produktivitas perusahaan yang menghasilkan produk kompleks secara signifikan sebesar -0.0405 . Selain itu, diketahui bahwa industri manufaktur memerlukan waktu kira-kira satu tahun untuk menyerap teknologi pada produk kompleks sehingga dapat meningkatkan produktivitas perusahaan. Produktivitas level perusahaan dihitung berdasarkan estimasi produktivitas Levinshon-Petrin untuk mengendalikan bias seleksi dan simultanitas.

${ }^{*}$ Corresponding Author

This is an open access article under the $\underline{\mathrm{CC}-\mathrm{BY}}$ license.

Sirma Oktaviani

E-mail: sirma.oktaviani@gmail.com

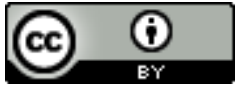




\section{PENDAHULUAN}

Penggunaan barang-barang impor menjadi saluran penting untuk mendapatkan teknologi baru sehingga dapat meningkatkan produktivitas dan pendapatan suatu negara. Output perusahaan tidak hanya bergantung pada kualitas unggul input bahan baku, tetapi juga pada variasi input yang tersedia [1]. Perusahaan yang menambahkan aktivitas perdagangan baru seperti mengimpor memiliki dampak positif pada kinerja perusahaan Hungaria [2]. Demikian pula, perusahaan yang beralih dari non-importir menjadi importir dapat meningkatkan produktivitas di pabrik manufaktur Chili [3].

Berdasarkan data survei Industri Besar dan Sedang (Badan Pusat Statistik) tahun 2010-2014, terdapat dua fenomena pengaruh impor bahan baku terhadap produktivitas industri di Indonesia. Industri yang memiliki nilai impor tinggi dapat saja memiliki produktivitas yang tinggi atau lebih rendah dibandingkan industri dengan nilai impor kecil. Industri bahan kimia dan barang dari bahan kimia (ISIC 20) dengan rata-rata nilai impor tertinggi yaitu $\mathrm{Rp} 69.94$ triliun memiliki produktivitas lebih rendah dibandingkan industri kendaraan bermotor (ISIC 29) dengan rata-rata nilai impor sebesar Rp 20.46 triliun.

Produktivitas sektor yang terus meningkat merupakan sumber utama dalam mendukung pertumbuhan ekonomi, sehingga keterkaitan antara impor bahan baku dan produktivitas sektor industri pengolahan non migas menjadi topik yang penting untuk diteliti, dimana sektor ini merupakan sumber utama dalam mendukung pertumbuhan ekonomi Indonesia [4]. Beberapa penelitian melaporkan bahwa impor input antara memiliki dampak negatif terhadap produktivitas atau tidak berpengaruh sama sekali (peningkatan produktivitasnya dapat diabaikan) [5], [9], [10]. Hal ini dapat terjadi karena daya saing dan konteks perusahaan yang pada awal nya sudah lemah [6], [7], [8], [11], [12]. Penggunaan input asing dapat meningkatkan produktivitas perusahaan, tetapi karena adanya biaya tetap impor, maka hanya perusahaan-perusahaan sangat produktif yang mengimpor input antara [13] .

Perusahaan dengan produktivitas tinggi mungkin mengimpor input antara lebih banyak untuk menghasilkan produk lebih banyak. Hal ini menunjukkan adanya hubungan timbal balik (kausalitas) antara produktivitas perusahaan dan impor bahan baku. Produktivitas perusahaan mempengaruhi keputusan perusahaan untuk berpartisipasi dalam kegiatan impor, dan sebaliknya, keputusan partisipasi ini mempengaruhi produktivitas perusahaan. Akan tetapi, penelitian ini memiliki keterbatasan yaitu hanya membahas pengaruh impor bahan baku terhadap produktivitas perusahaan.

Selain kegiatan impor, faktor lainnya yang dapat mempengaruhi produktivitas adalah kompleksitas produk. Salah satu ukuran kompleksitas produk adalah jumlah input yang berbeda untuk menghasilkan suatu produk [14]. Secara mendasar perusahaan dapat memilih apakah akan menghasilkan produk kompleks seperti pesawat terbang, atau produk yang lebih sederhana, seperti tekstil [14]. Permintaan produk kompleks menyebabkan peningkatan drastis pada jumlah penawaran produk tersebut di industri manufaktur [15], [16], [17], [18]. Peningkatan kompleksitas produk dapat menyebabkan kompleksitas dalam organisasi. Selain itu, kompleksitas produk dapat merusak kinerja operasional yang diukur dalam biaya tenaga kerja, biaya overhead pabrik, dan produktivitas perusahaan [19], [20], [21], [22], [23].

Beberapa penelitian sebelumnya juga menunjukkan adanya penurunan produktivitas yang terjadi karena kecepatan lini produksi berkurang, peningkatan downtime dan peningkatan proses penyesuaian pada lini produksi [24]. Hasil serupa menunjukkan terjadinya penurunan produktivitas ketika perusahaan yang mengimpor input antara merupakan perusahaan yang menghasilkan produk kompleks [25].

Dampak peningkatan kompleksitas produk terhadap sistem manufaktur yang jelas terlihat adalah meningkatnya biaya produksi [26]. Secara keseluruhan, peningkatan kompleksitas produk berpengaruh pada tingginya biaya manufakur, inventori dan distribusi sehingga dapat dikatakan kompleksitas produk menjadi prediktor penting variabilitas produktivitas suatu perusahaan.

Masing-masing produk memiliki tingkat kompleksitas produk yang berbeda-beda [27]. Produk yang termasuk kategori paling kompleks adalah mesin, bahan kimia dan logam, sedangkan produk yang sederhana adalah kayu, tekstil, dan produk pertanian. Berdasarkan kategori tersebut, ekspor produk Indonesia masih didominasi oleh produk sederhana. Nilai ekspor Indonesia untuk produk kompleks masih rendah diantaranya ratarata ekspor produk SITC kode 7 yaitu mesin dan alat pengangkutan sebesar US\$21.29 miliar (12.4\%) dan rata-rata ekspor produk SITC kode 5 
yaitu bahan-bahan kimia mesin dan alat pengangkutan sebesar US\$11.43 miliar (6.7\%).

Penelitian pengaruh impor bahan baku dan kompleksitas produk terhadap produktivitas perusahaan masih sedikit. Perusahaan yang menghasilkan produk homogen mendapat manfaat lebih besar dari input impor [28]. Perusahaan yang mengimpor input antara dan menghasilkan banyak produk kompleks akan memiliki produktivitas lebih rendah dibandingkan perusahaan yang menghasilkan produk sederhana [25]. Peningkatan kompleksitas produk juga dapat menurunkan probabilitas kepuasan importir dimana produk kompleks membutuhkan lebih banyak kemampuan mengadopsi teknologi (learning by doing) sehingga produktivitas perusahaan menjadi turun. Sebaliknya perusahaan yang menghasilkan produk sederhana akan lebih mudah mengadopsi teknologi yang berasal dari input impor.

Kategori produk kompleks yang digunakan pada penelitian [28] dan [25] mengikuti klasifikasi Rauch [29]. Klasifikasi tingkat kompleksitas sebagai produk yang tidak memiliki harga referensi atau produk yang harganya tidak dikutip pada pasar terorganisir [29]. Sebaliknya barang sederhana adalah barang yang dipertukarkan di pasar terorganisir atau barang yang memiliki harga referensi. Klasifikasi kompleks menggunakan dummy bernilai 1 untuk produk kompleks dan 0 untuk produk sederhana. Pengklasifikasian ini menjadi kurang tepat karena masing-masing industri memiliki tingkat kompleksitas produk yang berbeda.

Pada penelitian ini, penulis menggunakan pengukuran kompleksitas produk bernilai kontinu seperti yang telah diteliti oleh [30] dan [31]. Menurut [32], kompleksitas produk didefinisikan sebagai sejumlah kemampuan atau keterampilan tak berwujud yang diperlukan untuk menghasilkan produk yang baik. Semakin sedikit region (negara) yang menghasilkan suatu produk berarti semakin tinggi pula kapabilitas yang dibutuhkan untuk menghasilkan produk tersebut, sehingga produk ini termasuk dalam kategori kompleks. Konsep perhitungan Product Complexity Index (PCl) adalah dengan menghitung rata-rata keunikan suatu barang (ubiquity produk) sehingga indeks yang diperoleh sudah mencerminkan apakah produk tersebut juga dihasilkan oleh daerah yang menghasilkan banyak produk atau sedikit produk.

Penelitian ini menggunakan level perusahaan sesuai data hasil Survei Industri Besar dan Sedang (IBS) tahun 2010-1014 yang dikeluarkan
BPS, sedangkan level kompleksitas produk dihitung pada level KBLI tiga digit (ISIC Rev.4). Penelitian ini merupakan bukti empiris yang menunjukkan bahwa pengaruh impor bahan baku terhadap produktivitas perusahaan yang menghasilkan produk kompleks adalah negatif dan signifikan. Dengan menghitung kompleksitas produk pada masing-masing industri ISIC 3 digit maka dapat diketahui produk sederhana mendapatkan manfaat peningkatan produktivitas lebih besar dibandingkan produk kompleks. Hal ini dapat terjadi karena manfaat learning effect produk sederhana lebih besar. Perusahaan yang menghasilkan produk sederhana tidak membutuhkan teknologi spesifik, sedangkan produk kompleks membutuhkan lebih banyak kemampuan untuk mengadopsi teknologi. Selanjutnya, struktur dari penelitan ini terdiri dari Bab 2 yang akan menampilkan metode penelitian serta penjelasan data yang digunakan dalam pengolahan data. Bab 3 membahas hasil penelitan dan Bab 4 adalah Kesimpulan.

\section{METODE PENELITIAN}

Penelitian ini menggunakan prosedur berdasarkan penelitian [25] untuk mengeksplorasi hubungan antara impor bahan baku, produktivitas perusahaan dan kompleksitas produk. Tahap pertama yang dilakukan adalah menghitung produktivitas perusahaan dengan menggunakan metodologi augmented Olley-Pakes [33] dan Levinsohn-Petrin [34]. Pendekatan semiparametrik ini digunakan untuk mengatasi bias estimasi dan seleksi ketika menggunakan pendekatan OLS biasa untuk mengestimasi TFP. Kedua, memeriksa dampak impor input antara terhadap produktivitas perusahaan dengan menggunakan perkiraan fixed effect pada data panel. Ketiga, penulis menggunakan kompleksitas produk Hidalgo [32] dan [31] yang merupakan nilai kontinu, sehingga dapat membedakan kompleksitas untuk masing-masing industri di Indonesia.

Fungsi produksi suatu perusahaan dipengaruhi oleh input dan sisa produktivitas (productivity shock) sehingga output produksi dapat dijelaskan sebagai berikut:

$Y_{i t}=F\left(A_{i t}, X_{i t}\right)$

dimana $Y_{i t}$, $A_{i t}$ dan $X_{i t}$ adalah output produksi, teknologi dan vektor input produksi perusahaan i pada waktu t. Fungsi produksi memiliki sifat strictly increasing dan kontinu sehingga penambahan 1 unit input produksi akan berdampak pada peningkatan produksi $\left(\partial \mathrm{Y} / \partial \mathrm{X}_{\mathrm{i}}>0\right)$. Literatur 
tentang TFP biasanya menyarankan fungsi produksi Cobb-Douglas untuk peningkatan teknologi. Untuk mengestimasi produktivitas maka diasumsikan fungsi produksi menggunakan input yaitu K (kapital), L (tenaga kerja) dan M (material) sebagai berikut:

$Y_{i t}=F\left(A_{i t}, K_{i t}, L_{i t}, M_{i t}\right)$

$Y_{i t}=A_{i t} K_{i t}^{\beta_{1}} L_{i t}^{\beta_{2}} M_{i t}^{\beta_{3}}$

Selanjutnya memperkirakan persamaan dengan mengambil fungsi-log terlebih dahulu:

$$
\begin{aligned}
& \ln Y_{i t}=\ln A_{i t}+\ln K_{i t}^{\beta_{1}}+\ln L_{i t}^{\beta_{2}}+\ln M_{i t}^{\beta_{3}} \\
& \ln Y_{i t}=\beta_{0}+\beta_{1} \ln K_{i t}+\beta_{2} \ln L_{i t}+\beta_{3} \ln M_{i t}
\end{aligned}
$$

Karena nilai dari $\ln A_{\text {it }}$ adalah konstan maka simbolnya diubah menjadi $\beta_{0}$ yang mewakili intersep. Pada data panel, satu perusahaan akan muncul beberapa kali pada waktu yang berbeda, sehingga fungsi stokastik dari persamaan (5) menjadi persamaan (6). Perhitungan produktivitas $\left(\Omega_{i t}\right)$ kemudian dilakukan dengan menggunakan nilai residual Solow antara data sebenarnya $\left(\ln Y_{i t}\right)$ dan fitted value nya $\left(\ln \hat{Y}_{i t}\right)$ seperti pada persamaan (7).

$$
\begin{aligned}
& \ln Y_{i t}=\beta_{0}+\beta_{1} \ln K_{i t}+\beta_{2} \ln L_{i t}+\beta_{3} \ln M_{i t}+\varepsilon_{i t} \\
& \Omega_{i t}=\ln Y_{i t}-\ln \widehat{Y_{t}} \\
& \Omega_{i t}=\ln Y_{i t}-\widehat{\beta_{1}} \ln K_{i t}-\widehat{\beta_{2}} \ln L_{i t}-\widehat{\beta_{3}} \ln M_{i t}
\end{aligned}
$$

Seperti yang telah diuraikan sebelumnya, estimasi parameter persamaan (6) dengan menggunakan OLS dapat mengabaikan permasalahan bias seleksi dan bias simultan. Untuk mengatasi hal tersebut maka penelitian ini menggunakan metodologi augmented Olley-Pakes [33] dan Levinsohn-Petrin [34] untuk mengukur TFP.

\subsection{TFP Olley-Pakes}

Pendekatan Olley-Pakes [33] mengasumsikan bahwa pada awal periode setiap perusahaan yang ada di pasar akan memutuskan apakah tetap berada di pasar atau tidak. Jika keluar dari pasar, maka perusahaan menerima sejumlah nilai likuidasi $(\phi)$ dan tidak pernah muncul lagi. Jika tidak keluar, maka perusahaan akan memilih variabel input (tenaga kerja) dan tingkat investasi (lit) tertentu. Perusahaan juga menyadari bahwa profit tergantung pada variabel seperti indikator productivity shock $\left(\Omega_{i t}\right)$ dan persediaan modal (Kit) di awal periode.

Selanjutnya diasumsikan produktivitas yang diharapkan merupakan fungsi dari produktivitas dan kapital saat ini, $\mathrm{E}\left[\Omega_{i, t+1} \mid \Omega_{i t}, \mathrm{~K}_{i t}\right]$, dan profit perusahaan adalah fungsi dari $\Omega_{i t}$ dan $\mathrm{K}_{\mathrm{it}}$. Keputusan perusahaan untuk memaksimalkan nilai diskonto dari profit yang diharapkan dari laba bersih periode selanjutnya dengan karakteristik persamaan Bellman adalah:

$$
\begin{gathered}
V_{i t}\left(K_{i t}, \Omega_{i t}\right)=\operatorname{Max}\left[\Phi, \prod_{i t}(.)\right] \\
\prod_{i t}(.)=\operatorname{Sup}_{I_{i t}} \prod_{i t}\left(K_{i t}, \Omega_{i t}\right)-C\left(I_{i t}\right)+ \\
\rho E\left\{V_{i, t+1}\left(K_{i, t+1}, \Omega_{i, t+1}\right) \mid J_{i t}\right\}
\end{gathered}
$$

di mana $\prod_{i t}($.$) adalah fungsi profit, \mathrm{C}($.$) adalah$ biaya investasi saat ini, $\rho$ adalah discount factor dan $E\left\{. \mid J_{\text {it }}\right\}$ adalah kondisi harapan perusahaan yang bergantung pada informasi $J_{i t}$. Persamaan Bellman menyiratkan bahwa perusahaan keluar dari pasar jika nilai likuidasi $(\Phi)$ lebih besar daripada tingkat pengembalian yang diharapkan. Solusi untuk persamaan ini menghasilkan strategi keseimbangan Markov untuk mendefinisikan aturan perusahaan untuk keluar dari pasar dan untuk keputusan investasi. Secara spesifik, perusahaan i memutuskan untuk tetap berada di pasar $\left(X_{i t}=1\right)$ atau keluar dari pasar $\left(X_{i t}=0\right)$ jika produktivitasnya lebih besar atau kurang dari beberapa ambang batas yang dikenakan $\left(K_{i t}\right)$. Aturan keluar dari pasar ditulis sebagai berikut:

$\chi_{i t}=\left\{\begin{array}{l}1, j i k a \Omega_{i t} \geq \underline{\Omega_{i t}}\left(K_{i t}\right) \\ 0, j i k a \Omega_{i t}<\underline{\Omega_{i t}}\left(K_{i t}\right)\end{array}\right.$

Diasumsikan $\Omega_{i t}$ mengikuti proses Markov orde pertama. Keputusan perusahaan untuk investasi dipengaruhi oleh $\Omega_{i t}$ dan $K_{i t}$ :

$I_{i t}=I\left(\Omega_{i t}, K_{i t}\right)$

Persamaan (12) menyiratkan bahwa produktivitas masa depan akan meningkat karena productivity shock saat ini, sehingga perusahaan yang mengalami productivity shock positif pada periode $t$ akan berinvestasi lebih banyak pada periode $t+1$. Berdasarkan persamaan (11), Olley-Pakes menentukan parameter fungsi produksi secara konsisten. Dengan mengasumsikan teknologi sebagai fungsi produksi yang menghubungkan output dengan input dan sisa productivity shock, maka $\varepsilon_{i t}$ pada persamaan (6) menjadi:

$$
\begin{aligned}
& \varepsilon_{i t}=\Omega_{i t}+\eta_{i t} \\
& \ln Y_{i t}=\beta_{0}+\beta_{1} \ln K_{i t}+\beta_{2} \ln L_{i t}+\beta_{3} \ln M_{i t}+\Omega_{i t}+ \\
& \eta_{i t}
\end{aligned}
$$

dimana $\Omega_{i t}$ adalah productivity shock yang diamati oleh pembuat keputusan di perusahaan dan $\eta_{i t}$ adalah productivity shock tak terduga yang tidak diamati oleh pembuat keputusan. Dengan demikian $\eta_{i t}$ tidak berpengaruh pada keputusan 
perusahaan sedangkan $\Omega_{i t}$ adalah variabel yang mempengaruhi proses pengambilan keputusan perusahaan. Ketika nilai lit pada persamaan (12) benar-benar positif maka persamaan tersebut dapat ditulis sebagai fungsi invers untuk productivity shock yang tidak teramati $\left(\Omega_{i t}\right)$.

$\Omega_{i t}=I^{-1}\left(I_{i t}, K_{i t}\right)=h\left(I_{i t}, K_{i t}\right)$

dimana $I_{i t}$ adalah nilai yang benar-benar meningkat (strictly increasing). Persamaan (15) dapat digunakan untuk mengontrol masalah simultanitas. Dengan memasukkan persamaan (15) ke persamaan (14) maka diperoleh:

$$
\begin{aligned}
& \ln Y_{i t}=\beta_{0}+\beta_{1} \ln K_{i t}+\beta_{2} \ln L_{i t}+\beta_{3} \ln M_{i t}+ \\
& \quad h\left(\ln I_{i t}, \ln K_{i t}\right)+\eta_{i t} \\
& y_{i t}=\beta_{0}+\beta_{1} k_{i t}+\beta_{2} l_{i t}+\beta_{3} m_{i t}+h\left(i_{i t}, k_{i t}\right)+\eta_{i t} \\
& \theta\left(i_{i t}, k_{i t}\right)=\beta_{0}+\beta_{1} k_{i t}+h\left(i_{i t}, k_{i t}\right) \\
& y_{i t}=\beta_{2} l_{i t}+\beta_{3} m_{i t}+\theta\left(i_{i t}, k_{i t}\right)+\eta_{i t}
\end{aligned}
$$

Selanjutnya diasumsikan $\theta($.$) adalah persamaan$ polinomial orde kedua untuk kapital dan investasi yang dapat diestimasi menggunakan metode OLS. Estimasi koefisien untuk input variabel (tenaga kerja dan material) akan konsisten karena $\theta($.$) mengontrol produktivitas yang tidak teramati$ sehingga term error tidak lagi berkorelasi dengan variabel input. Persamaan (19) tidak mengidentifikasi $\beta_{3}$ sehingga lebih banyak tahapan diperlukan untuk menguraikan efek kapital pada keputusan investasi dan pengaruhnya terhadap output. Tahap kedua adalah memperkirakan probabilitas kelangsungan hidup perusahaan sehingga dapat menghindari bias seleksi. Berdasarkan persamaan (11) probabilitas perusahaan tetap berada di pasar pada periode $\mathrm{t}$ bergantung pada $\Omega_{\mathrm{i}, \mathrm{t}-1}$ dan $\Omega_{\mathrm{i}, \mathrm{t}-\mathrm{t}}$. Probabilitas perusahaan bertahan di pasar $\left(\hat{P}_{i t}\right)$ mengikuti model probit $X_{\text {it }}$ pada $I_{i, t-1}$ dan $K_{i, t-1}$. Tahap ketiga adalah menyelesaikan persamaan dibawah ini dengan metode Nonlinier least squres:

$$
\begin{gathered}
y_{i t}-\widehat{\beta_{2}} l_{i t}-\widehat{\beta_{3}} m_{i t}=\beta_{1} k_{i t}+g\left(\widehat{\theta_{t-1}}-\right. \\
\left.\beta_{1} k_{i, t-1}, \widehat{P_{l t}}\right)+\xi_{i t}+\eta_{i t}
\end{gathered}
$$

dimana fungsi $\mathrm{g}($.$) yang tidak diketahui didekati$ oleh polinomial orde kedua di $\overline{\theta_{t-1}}-\beta_{1} k_{i, t-1}$ dan $\widehat{P_{l t}}$. Karena estimasi TFP OP terdiri dari tiga tahap maka akan menghasilkan analitik standard errors yang nontrivial.

\subsection{TFP Levinsohn-Petrin}

Salah satu kelemahan estimator TFP OP adalah penggunaan nilai investasi perusahan sebagai proksi productivity shocks yang tidak teramati. Perusahaan tidak secara rutin melaporkan biaya investasi yang dikeluarkan oleh perusahaan pada survei industr, bahkan banyak perusahaan melaporkan investasi dengan nilai nol, sehingga timbul keraguan pada motonitas fungsi investasi. Levinsohn dan Petrin [34] menawarkan solusi yang lebih baik untuk mengatasi bias simultan, yaitu dengan menggunakan proksi input antara dimana perusahaan selalu melaporkan pembelian input antara pada survei industri.

Levinsohn dan Petrin [34] mengusulkan untuk menetapkan fungsi kontrol dari nilai investasi menjadi nilai input perantara yang bernilai positif dan nilainya selalu dilaporkan oleh perusahaan. Dengan demikian, proksi untuk produktivitas pada estimator LP menjadi seperti pada persamaan (21), sehingga persamaan (14) menjadi persamaan (22) dan seterusnya.

$\Omega_{i t}=h\left(M_{i t}, K_{i t}\right)$

$\ln Y_{i t}=\beta_{0}+\beta_{1} \ln K_{i t}+\beta_{2} \ln L_{i t}+\beta_{3} \ln M_{i t}+$ $h\left(\ln M_{i t}, \ln K_{i t}\right)+\eta_{i t}$

$y_{i t}=\beta_{0}+\beta_{1} k_{i t}+\beta_{2} l_{i t}+\beta_{3} m_{i t}+h\left(m_{i t}, k_{i t}\right)+\eta_{i t}$

$\theta\left(m_{i t}, k_{i t}\right)=\beta_{0}+\beta_{1} k_{i t}+\beta_{3} m_{i t}+h\left(m_{i t}, k_{i t}\right)$

$y_{i t}=\beta_{2} l_{i t}+\theta\left(m_{i t}, k_{i t}\right)+\eta_{i t}$

Estimasi $\widehat{\beta_{2}}$ dihitung persis pada tahap TFP OP yaitu dengan mengasumsikan $\theta\left(m_{i t}, k_{i t}\right)$ adalah persamaan polinomial orde kedua untuk kapital $\left(k_{i t}\right)$ dan material $\left(m_{i t}\right)$ melalui metode OLS. Untuk setiap nilai kandidat $\widehat{\beta_{1}}$ dan $\widehat{\beta_{3}}$ pada persamaan (24), nilai $\widehat{h_{l t}}$ diestimasi dengan cara:

$\hat{h}\left(m_{i t}, k_{i t}\right)=\hat{\theta}\left(m_{i t}, k_{i t}\right)-\widehat{\beta_{1}} k_{i t}-\widehat{\beta_{3}} m_{i t}$

Menggunakan hit untuk semua $t$, maka $E\left[h_{t} \mid h_{l, t-1}\right]$ juga dihitung sesuai dengan tahap TFP-OP, kemudian residual $\beta_{1}{ }^{*}$ dan $\beta_{3}{ }^{*}$ dihitung dengan cara:

$$
\begin{gathered}
\eta_{i t} \widehat{+\xi_{i t}}=y_{i t}-\widehat{\beta_{2}} l_{i t}-\widehat{\beta_{1}} k_{i t}-\widehat{\beta_{3}} m_{i t}- \\
E\left[h_{l t} \widehat{\mid h_{l, t}-1}\right]
\end{gathered}
$$

Residual ini harus berinteraksi dengan setidaknya dua instrumen untuk mengidentifikasi $\beta_{1}$ dan $\beta_{3}$. Jika stok modal periode t pada TFP-OP ditentukan oleh keputusan investasi periode sebelumnya, maka pada metode ini, tidak ada guncangan sehingga $E\left[\eta_{i t}+\xi_{i t} \mid k_{t}\right]=0$ yang secara implisit dikenakan dalam fungsi obyektif dari persamaan 
(23). Kondisi tambahan diperlukan untuk mengidentifikasi $\beta_{3}$ secara terpisah dari $\beta_{1}$. LP menggunakan fakta bahwa tingkat penggunaan material pada periode sebelumnya $m_{i t}$ tidak berkorelasi dengan error periode ini, sehingga diperoleh $\mathrm{E}\left[\eta_{\mathrm{it}}+\xi_{i t} \mid \mathrm{m}_{\mathrm{t}-1}\right]=0$. Jadi, dengan $\mathrm{Z}_{\mathrm{t}} \equiv$ $\left(\mathrm{k}_{\mathrm{t}}, \mathrm{m}_{\mathrm{t}-1}\right), \widehat{\beta_{1}}$ dan $\widehat{\beta_{3}}$ kemudian didefinisikan sebagai solusi dari $\left.\min _{\left(\overline{\beta_{1}}, \bar{\beta}_{3}\right.}\right) \sum_{h}\left\{\sum_{t}\left(\widehat{\eta_{t}+\xi_{t}}\right) Z_{h t}\right\}^{2}$.

\subsection{Kompleksitas Produk}

Konsep kompleksitas produk pertama kali diperkenalkan dalam literatur empiris tentang perdagangan. Rauch [29] adalah yang pertama berpendapat bahwa hambatan perdagangan bergantung pada tingkat diferensiabilitas produk yang diperdagangkan. Rauch mengklasifikasikan tingkatan diferensiasi produk atau kompleksitas sebagai produk yang tidak memiliki harga referensi atau yang harganya tidak dikutip pada pasar yang terorganisir. Sebaliknya barang sederhana adalah barang yang dipertukarkan di pasar terorganisir atau barang yang memiliki harga referensi. Klasifikasi kompleks menggunakan dummy bernilai 1 untuk barang kompleks dan 0 untuk barang sederhana.

Penelitian ini menggunakan Metode Refleksi yang dikembangkan oleh Hidalgo [30] untuk membangun ukuran kompleksitas produk dan negara. Metode ini menggunakan data perdagangan internasional yang saling eksklusif antara set negara dan produk ekspor masingmasing negara dengan keunggulan komparatif (Revealed Comparatif Advantage). Metode Refleksi menunjukkan bahwa negara-negara dengan serangkaian kemampuan tersedia yang lebih luas cenderung memiliki struktur produksi lebih beragam sehingga negara tersebut mampu mengekspor produk yang lebih eksklusif.

Metode Refleksi mampu mengekstraksi informasi relevan tentang ketersediaan kapabilitas negara dan kapabilitas yang dibutuhkan oleh produk dari struktur jaringan produk negara bipartit. Dua estimasi awal yang digunakan pada metode ini adalah diversifikasi produk dan ubiquity produk. Diversifikasi produk menunjukkan jumlah produk yang diekspor suatu negara dengan RCA, yang secara positif berkaitan dengan jumlah kemampuan tersedia di suatu negara. Ubiquity produk menunjukkan jumlah negara yang mengekspor produk dengan RCA, berbanding terbalik dengan kompleksitas produk. Produk yang melibatkan kompetensi lebih spesifik akan diproduksi dan diekspor di negara yang lebih sedikit daripada barang standar lainnya.

Metode Refleksi secara iteratif menghitung ukuran kompleksitas yang menggabungkan kedua jenis informasi tersebut, yaitu diversifikasi dan ubiquity. Iterasi akan dilakukan sampai tidak ada lagi informasi tambahan untuk diekstrak. Dengan demikian, Product Complexity Index (PCl) dibangun dengan menghitung keragaman ratarata negara yang membuat produk tersebut dan ubiquity produk lain yang dibuat oleh negaranegara ini. Posisi suatu produk dalam peringkat kompleksitas ditentukan oleh nilai PCI. Semakin tinggi nilai $\mathrm{PCl}$ dan semakin tinggi posisi produk maka semakin kompleks produksinya.

Berdasarkan penjelasan diatas maka tahapan untuk menghitung $\mathrm{PCl}$ adalah sebagai berikut:

1. Mengidentifikasi apakah suatu negara merupakan pengekspor produk signifikan atau tidak, yaitu dengan menghitung Revealed Comparative Advantage (RCA) yang dimiliki negara tersebut untuk produk tertentu. RCA merupakan share sebuah produk yang diekspor oleh sebuah negara terhadap total ekspor di seluruh dunia [35]. Definisi Balassa tentang RCA menunjukkan bahwa suatu negara pada produk $p$ dengan $R C A \geq 1$ terjadi jika negara mengekspor produk $p$ lebih dari bagian yang sama atau lebih besar dari pangsa total perdagangan dunia yang diwakili oleh produk tersebut. Secara formal, RCA yang dimiliki negara $c$ dalam produk $p$ dapat dinyatakan sebagai:

$R C A_{c p}=\frac{X_{c p} / \Sigma_{c} X_{c p}}{\sum_{p} X_{c p} / \Sigma_{c, p} X_{c p}}$

dimana:

$X_{c p} \quad$ : nilai ekspor suatu produk $p$ yang dihasilkan oleh sebuah negara $\mathrm{c}$

$\Sigma_{\mathrm{c}} \mathrm{X}_{\mathrm{cp}}$ : total nilai ekspor semua produk yang dihasilkan oleh sebuah negara $\mathrm{c}$

$\Sigma_{\mathrm{p}} \mathrm{X}_{\mathrm{cp}}$ : total nilai ekspor suatu produk $\mathrm{p}$ yang dihasilkan oleh semua negara di dunia $\Sigma_{c, p} X_{c p}$ : total nilai ekspor dunia (seluruh produk yang dihasilkan di seluruh dunia)

Tidak semua produksi yang dihasilkan suatu negara dapat diakui sebagai kapabilitas keragaman produk [36]. Hanya produk yang diekspor dengan nilai $R C A \geq 1$ dan tidak termasuk produk jasa yang dapat dimasukkan dalam dasar perhitungan kompleksitas. 
2. Mengidentifikasi matriks keragaman dan ubiquity produk yang meringkas negara mana membuat produk apa saja. Nilai RCA pada persamaan (28) tidak dapat langsung digunakan untuk menyusun matriks ini karena RCA sensitif terhadap perubahan harga. Selain itu, jika keranjang ekspor suatu negara didominasi oleh beberapa produk, maka lebih sulit bagi produk lain mana pun untuk menunjukkan nilai RCA yang lebih tinggi walaupun negara tersebut membuatnya. Entri dalam matriks ini (matriks $M_{\mathrm{cp}}$ ) menggunakan nilai RCA dengan ketentuan sebagai berikut:

$M_{c p}=\left\{\begin{array}{l}1 \text { jika } R C A_{c p} \geq 1 \\ 0, j i k a R C A_{c p}<1\end{array}\right.$

Hasil akhir di tahap pertama adalah matriks $M_{\mathrm{cp}}$ bernilai 1 dan 0 yaitu matriks yang menghubungkan setiap negara dengan keunggulan produk yang dihasilkannya.

3. Mengidentifikasi diversifikasi (keragaman) produk di suatu negara. Tahap ini menjelaskan seberapa banyak dan beragamnya produk unggulan yang dapat dihasilkan oleh sebuah negara. Model matematika yang menerangkan konsep keragaman adalah:

Keragaman $=k_{c, 0}=\sum_{p} M_{c p}$

dimana:

$\sum_{p} M_{c p} \quad$ : jumlah nilai 1 atas setiap produk $\mathrm{p}$ yang dihasilkan sebuah negara $\mathrm{c}$ pada matriks Mcp

Semakin besar nilai keragaman pada persamaan (30) maka kapabilitas sebuah negara semakin tinggi dan tingkat keragaman produk yang dihasikan juga semakin tinggi. Begitu juga sebaliknya, sebuah negara dengan tingkat ilmu pengetahuan dan teknologi yang rendah maka kapabilitasnya juga semakin rendah sehingga barang yang diproduksi pun semakin sedikit. Dengan kata lain keragaman produk nya semakin rendah. Hasil perhitungan di tahap ini menghasilkan vektor keragaman produk $\left[k_{c, 0}\right]$

4. Mengidentifikasi ubiquity produk yang menggambarkan seberapa banyak negara dapat membuat produk tertentu. Model matematika yang menerangkan konsep ubiquity produk adalah:

$$
\text { Ubiquity }=k_{p, 0}=\sum_{c} M_{c p}
$$

dimana:

$\sum_{c} M_{c p} \quad$ : jumlah nilai 1 atas setiap negara $c$ yang dapat menghasilkan sebuah produk $p$ pada matriks $M_{c p}$

Semakin tinggi kapabilitas yang dibutuhkan untuk menghasilkan produk tertentu maka semakin sedikit negara yang mampu memproduksinya. Sehingga dapat dikatakan, semakin rendah tingkat ubiquity produk maka semakin unggul sebuah negara untuk memproduksi produk tersebut karena hanya sedikit negara yang menghasilkannya, begitu juga sebaliknya. Hasil perhitungan di tahap ini menghasilkan vektor ubiquity produk $\left[k_{\mathrm{p}, 0}\right]$.

5. Berdasarkan tahap 2-4, dapat dikatakan negara yang mengekspor lebih banyak produk unggul lebih terdiversifikasi daripada negara yang mengekspor lebih sedikit produk unggul (kurang terdiversifikasi). Selain itu, produk unggul yang diekspor oleh lebih sedikit negara (less ubiquitous) disebut lebih kompleks daripada produk unggul diekspor oleh lebih banyak negara (more ubiquitous). Intuisi di balik ini adalah suatu negara dapat mengekspor produk unggul jika memiliki kemampuan spesifik (keterampilan tenaga kerja, lembaga, mesin, input publik dan input yang dapat diperdagangkan) yang diperlukan oleh produk tersebut. Begitu pula suatu produk yang less ubiquitous akan membutuhkan kemampuan yang lebih eksklusif.

Hasil dari tahap 3 dan 4 hanya menunjukkan derajat node dalam jaringan bipartit yaitu vektor keragaman produk $\left(k_{c, 0}\right)$ dan vektor ubiquity produk $\left(k_{p}, 0\right)$. Tahapan ini belum dapat mengkarakterisasi struktur jaringan tersebut sehingga diperlukan Metode Refleksi yang secara matematis dapat ditulis sebagai berikut:

$k_{c, n}=\frac{1}{k_{c, 0}} \sum_{p} M_{c p} \cdot k_{p, n-1}$
$k_{p, n}=\frac{1}{k_{p, 0}} \sum_{c} M_{c p} \cdot k_{c, n-1}$

dimana $\mathrm{n}$ adalah jumlah iterasi.

Metode ini menggabungkan konsep ubiquity dan diversifikasi berdasarkan struktur jaringan bipartit. Informasi yang diperoleh dengan menggunakan metode ini adalah informasi mengenai rata-rata ubiquity produk yang diekspor oleh suatu negara $\left(k_{c}, 1\right)$ serta rata-rata diversifikasi negara yang mengekspor produk tertentu $\left(k_{p, 1}\right)$. Metode refleksi memungkinkan kita untuk mengkarakterisasi struktur jaringan bipartit sebanyak $\mathrm{n}$ iterasi. Misalnya, melanjutkan karakterisasi jaringan produk-negara ke dalam analisis lapisan ketiga di 
mana $\mathrm{k}_{\mathrm{c}, 2}$ adalah rata-rata $\mathrm{k}_{\mathrm{p}, 1}$ produk ekspor suatu negara, dan $\mathrm{k}_{\mathrm{p}, 2}$ adalah rata-rata $\mathrm{k}_{\mathrm{c}, 1}$ negara pengekspor. Iterasi selanjutnya dari metode refleksi dapat menyempurnakan ukuran kompleksitas yaitu dengan memperhitungkan informasi dari iterasi sebelumnya.

Hasil dari tahap iterasi metode refleksi adalah sepasang indeks, $\mathrm{k}_{\mathrm{c}, \mathrm{n}}$ dan $\mathrm{k}_{\mathrm{p}}, \mathrm{n}$, yang secara tidak langsung mengukur kemampuan yang tersedia secara lokal di suatu negara (kompleksitas ekonomi) dan kemampuan yang dibutuhkan oleh suatu produk (kecanggihan produk). Negaranegara dengan ranking $\mathrm{k}_{\mathrm{c}, \mathrm{n}}$ tinggi adalah negaranegara dengan struktur produktif yang memiliki banyak kemampuan, sementara negara dengan raning $\mathrm{k}_{\mathrm{c}, \mathrm{n}}$ rendah memiliki struktur produktivitas dengan sedikit kapabilitas. Demikian juga, produk dengan nilai $k_{p, n}$ tinggi adalah produk yang membutuhkan banyak kemampuan eksklusif, begitu juga sebaliknya.

[32] menggunakan proses berulang yang memakan waktu lebih lama sedangkan [31] mengimplementasikan penggunaan vektor eigen yang terkait dengan negara dan produk untuk memperoleh indeks kompleksitas ekonomi dan produk. Dengan memasukkan Persamaan (32) ke Persamaan (33) maka diperoleh:

$k_{p, n}=\frac{1}{k_{p, 0}} \sum_{c} M_{c p} \cdot \frac{1}{k_{c, 0}} \sum_{p^{\prime}} M_{c p} \cdot k_{p^{\prime}, n-2}$

$k_{p, n}=\sum_{p^{\prime}} k_{p \prime, n-2} \frac{1}{k_{p, 0}} \sum_{c} M_{c p} \cdot M_{c p} \cdot \frac{1}{k_{c, 0}}$

$k_{p, n}=\sum_{p \prime} k_{p \prime, n-2} \sum_{c} \frac{M_{c p} M_{c p \prime}}{k_{p, 0} k_{c, 0}}$

$k_{p, n}=\sum_{p} k_{p \prime, n-2} \widetilde{M}_{p p}$

dimana

$\widetilde{M}_{p p,}=\sum_{c} \frac{M_{c p} M_{c p \prime}}{k_{p, 0} k_{c, 0}}$

Persamaan (37) terpenuhi jika $k_{p, n} \infty k_{p, n-2 .}$ Hubungan ini terpenuhi jika $k_{p, n}$ adalah vektor eigen dari $\widetilde{M}_{p p}$. Vektor eigen terbesar dari matriks $\widetilde{M}_{p p}$, adalah vektor bernilai satu yang tidak menangkap variasi produk ekspor di semua negara, sehingga vektor eigen yang digunakan adalah vektor nilai eigen terbesar kedua. Vektor ini menangkap jumlah varians terbesar dalam sistem dan dapat digunakan dalam pengukuran kompleksitas. Dengan demikian, Product Complexity Index (PCl) didasarkan pada normalisasi vektor eigen dengan nilai eigen terbesar kedua dari $\widetilde{M}_{p p}$.
$P C I=\frac{\vec{Q}-\langle\vec{Q}\rangle}{\operatorname{stdev}\langle\vec{Q}\rangle}$

dimana

$\vec{Q} \quad$ : vektor eigen dengan nilai eigen terbesar kedua dari $\widetilde{M}_{p p}$

$\langle\vec{Q}\rangle \quad$ : rata-rata nilai eigen pada $\vec{Q}$

stdev $\langle\vec{Q}\rangle$ : standar deviasi nilai eigen pada $\vec{Q}$

Sebaliknya, dengan memasukkan Persamaan (33) ke Persamaan (32) maka diperoleh:

$k_{c, n}=\frac{1}{k_{c, 0}} \sum_{p} M_{c p} \cdot \frac{1}{k_{p, 0}} \sum_{c^{\prime}} M_{c^{\prime} p} \cdot k_{c^{\prime}, n-2}$

$k_{c, n}=\sum_{c^{\prime}} k_{c^{\prime}, n-2} \frac{1}{k_{c, 0}} \sum_{p} M_{c p} \cdot M_{c^{\prime} p} \cdot \frac{1}{k_{p, 0}}$

$k_{c, n}=\sum_{c^{\prime}} k_{c^{\prime}, n-2} \sum_{p} \frac{M_{c p} M_{c^{\prime} p}}{k_{c, 0} k_{p, 0}}$

$k_{c, n}=\sum_{c^{\prime}} k_{c \prime, n-2} \widetilde{M}_{c c^{\prime}}$

dimana

$\widetilde{M}_{c C^{\prime}}=\sum_{p} \frac{M_{c p} M_{c \prime}}{k_{c, 0} k_{p, 0}}$

Dengan mengikuti analogi yang sama untuk menghitung $\mathrm{PCl}$ maka Economic Complexity Index $(\mathrm{ECl})$ didasarkan pada normalisasi vektor eigen dengan nilai eigen terbesar kedua dari $\widetilde{M}_{c c 1}$

$E C I=\frac{\vec{C}-\langle\vec{C}\rangle}{\operatorname{stdev}\langle\vec{C}\rangle}$

dimana

$\vec{C} \quad$ : vektor eigen dengan nilai eigen terbesar kedua dari $\widetilde{M}_{c c \prime}$

$\langle\vec{C}\rangle \quad$ : rata-rata nilai eigen pada $\vec{C}$

stdev $\langle\vec{C}\rangle$ : standar deviasi nilai eigen pada $\vec{C}$

\subsection{Model Ekonometrika}

Untuk menyelidiki pengaruh impor input antara (impor bahan baku) terhadap produktivitas perusahaan maka peneliti menggunakan kerangka kerja empiris berikut:

$$
\begin{aligned}
& \ln T F P_{i t}=\beta_{0}+\beta_{1} \operatorname{lnIBB_{it}}+\beta_{2} P C I_{j t}+\beta_{3} \operatorname{lnIBB_{it}} \times \\
& P C I_{j t}+\beta_{4} P M A_{i j t}+\beta_{5} B U M N_{i t}+\beta_{6} D T_{i t}+ \\
& \bar{\omega}_{i}+\eta_{t}+\mu_{i j t}(46)
\end{aligned}
$$

dimana:

$\operatorname{lnTFP} P_{i t}$ : Produktivitas perusahaan diukur berdasarkan pendekatan nilai produksi $(\mathrm{Y})$

$I B B_{i t}$ : Impor Bahan Baku perusahaan $\mathrm{i}$ tahun $\mathrm{t}$ (dalam Ribu Rupiah). 
$P M A_{i t}$ : Karakteristik perusahaan i tahun $\mathrm{t}$ yang dilihat berdasarkan status kepemilikan perusahaan, bernilai 1 jika status kepemilikan saham asing $\geq 20$ persen dan 0 jika lainnya.

$B U M N_{i t}$ : Karakteristik perusahaan i tahun $t$ berdasarkan status kepemilikan modal pemerintah, bernilai 1 jika modal pemerintah pusat $\geq 51$ persen dan 0 jika lainnya.

$D T_{i t}$ : dummy teknologi perusahaan $\mathrm{i}$ tahun $\mathrm{t}$ berdasarkan klasifikasi UNIDO. Empat kelompok industri tersebut adalah industri teknologi rendah (ISIC 10-19, 25 dan 31), industri teknologi menengah (ISIC 22-24, 3233) dan industri teknologi tinggi-menengah (ISIC 20-21, 26-30)

$P C I_{j t}$ : Indikator kompleksitas produk dengan nilai kontinu yang dihitung berdasarkan metode Hidalgo [32].

$\ln I B B_{i t} \times P C I_{j t}$ : Variabel interaksi antara impor bahan baku dan kompleksitas produk di ISIC 3 digit.

$P M A_{i t}, B U M N_{i t}$ dan $D T_{i t}$ merupakan variabel kontrol yang menunjukkan karakteristik perusahaan dan diperkirakan dapat mempengaruhi produktivitas perusahaan. Error term pada persamaan (46) terdiri dari tiga komponen yaitu : (i) fixed-effect perusahaan i $\left(\bar{\omega}_{i}\right)$ untuk mengontrol faktor invarian waktu; (ii) fixed-effect untuk waktu $\mathrm{t}\left(\eta_{t}\right)$ untuk mengendalikan faktor invarian perusahaan dan (iii) efek idiosyncratic $\left(\mu_{i j t}\right)$ dengan distribusi normal $\mu_{i j t} \sim \mathrm{N}\left(0, \sigma_{i}^{2}\right)$ untuk mengendalikan faktorfaktor lain yang tidak ditentukan.

\section{HASIL DAN PEMBAHASAN}

Dataset awal yang digunakan adalah unbalanced panel data perusahaan industri besar dan sedang tahun 2010-2014 pada 24 sektor industri ISIC 2 digit atau 70 sub sektor industri ISIC 3 digit. Beberapa variabel yang diperlukan untuk mengestimasi fungsi produksi adalah output, kapital, tenaga kerja, material dan investasi. Pelaporan survei oleh perusahaan yang tidak stabil menyebabkan beberapa nilai pada variabel tersebut tidak lengkap sehingga data bernilai negatif, nol dan missing value dikeluarkan dari setdata karena semua variabel akan diubah dalam bentuk logaritma natural. Estimasi koefisien menggunakan empat cara yaitu
Ordinary Least Squre (OLS), Fixed Effect (FE), Olley-Pakes (OP) dan Levinsohn-Petrin (LP), dengan hasil estimasi seperti pada Tabel 1.

Hasil dari regresi OLS (model 1) untuk sampel sebanyak 71,765 menghasilkan koefisien kapital 0.0963 , koefisien input tenaga kerja 0.368 dan koefisien material 0.665 . Secara teoritis, estimator FE mengoreksi bias simultanitas dan bias seleksi. Melalui estimator FE (model 2), dapat dikatakan bahwa fungsi produksi dipengaruhi oleh perilaku perusahaan yang tidak berubah sepanjang waktu $\left(\bar{\omega}_{i}\right)$, sehingga diharapkan nilai koefisien pada variabel input (tenaga kerja dan material) lebih rendah dibandingkan estimator OLS. Sedangkan nilai koefisien untuk variabel kapital diharapkan lebih tinggi. Hasil dari regresi FE (model 2) menunjukkan nilai koefisien variabel input sesuai dengan harapan tetapi nilai koefisien variabel kapital masih sangat rendah. Koefisien input tenaga kerja dan material masing-masing turun menjadi 0.282 dan 0.617. Akan tetapi koefisien kapital turun drastis menjadi 0.0053 . Hal ini dapat terjadi karena kesalahan pengukuran nilai kapital pada survei dan variabilitas nilai kapital yang terjadi.

Hasil estimasi OLS dan OP juga mengikuti ekspektasi mengenai bias masalah simultan dan seleksi. Ketika bias ini tidak dikendalikan, koefisien terkait variabel input (tenaga kerja dan material) diharapkan memiliki bias ke atas, dan koefisien yang terkait dengan input kuasi-tetap (kapital) diharapkan akan bias ke bawah. Hasil pada model (3) menunjukkan koefisien pada variabel input bergerak ke arah yang menyarankan penghapusan bias ini.

Koefisien input tenaga kerja dan material masingmasing turun menjadi 0.330 dan 0.634 . Probabilitas kelangsungan hidup yang diperkirakan dari algoritma estimasi OP berdampak kecil pada koefisien kapital. Hasil ini sejalan dengan temuan OP, yang juga tidak menemukan peningkatan signifikan dalam koefisien kapital dari koreksi eksplisit untuk bertahan hidup ketika menggunakan unbalanced panel data. Dengan demikian mengendalikan bias simultan dan seleksi sangat penting karena terdapat perbedaan nilai koefisien yang cukup besar.

Tabel 1. Estimasi Fungsi Produksi Tahun 2010-2014

\begin{tabular}{lcccc}
\hline & $(1)$ & $(2)$ & $(3)$ & $(4)$ \\
& OLS & FE & OP & LP \\
\hline $\begin{array}{lllll}\text { Variabel } \\
\text { Kapital }\end{array}$ & $0.0963^{\star * *}$ & $0.0053^{*}$ & $0.0396^{* \star *}$ & $0.0286^{\star * *}$
\end{tabular}




\begin{tabular}{lcccc}
\hline & $(1)$ & $(2)$ & $(3)$ & $(4)$ \\
& OLS & FE & OP & LP \\
\hline \multirow{2}{*}{ Tenaga Kerja } & -0.0016 & -0.0023 & -0.0074 & -0.0041 \\
& $0.368^{* * *}$ & $0.282^{* * *}$ & $0.330^{* * *}$ & $0.309^{* * *}$ \\
Material & -0.0033 & -0.0062 & -0.0111 & -0.0078 \\
& $0.665^{* * *}$ & $0.617^{* * *}$ & $0.634^{* \star *}$ & $0.655^{\star \star *}$ \\
_cons & -0.0017 & -0.0022 & -0.0089 & -0.0067 \\
& $2.883^{* * *}$ & $5.233^{* * *}$ & & \\
$\mathrm{~N}$ & -0.0202 & -0.0468 & & \\
\hline R2 & 71,765 & 71,765 & 28,963 & 71,765 \\
\hline
\end{tabular}

Keterangan: Semua variabel dinyatakan dalam bentuk logaritma natural. Angka dalam kurung menunjukkan standard error. ${ }^{*},{ }^{* *}$, dan ${ }^{* * *}$ menunjukkan signifikansi masingmasing sebesar $10 \%, 5 \%$ dan $1 \%$.

Selain itu, perbandingan estimasi OLS dan LP juga menunjukkan hal yang sama, dimana parameter taksiran OLS variabel input (tenaga kerja dan material) melebihi taksiran LP. Koefisien input tenaga kerja dan material masing-masing turun menjadi 0.309 dan 0.655 . Hal ini menunjukkan bahwa besarnya productivity shock bervariasi dari waktu ke waktu dan bukan merupakan efek tetap yang konstan.

Berdasarkan uraian diatas dapat dilihat bahwa estimasi TFP-LP menunjukkan kondisi di mana input antara (material) dapat memecahkan masalah simultan yang terjadi. TFP-LP memperluas pilihan proxy yang ditetapkan oleh TFP-OP dan memberikan bukti empiris bahwa manfaat ini penting. Proksi investasi pada estimasi TFP-OP hanya berlaku untuk perusahaan yang melaporkan investasi bukan nol. Dengan menggunakan estimasi TFP-OP pada data perusahaan di Indonesia maka terjadi pemotongan data yang sangat besar. Selanjutnya perhitungan produktivitas (TFP) menggunakan fungsi produksi pada model (4) dengan estimasi TFP-LP.

Nilai PCI untuk setiap ISIC 3 digit berbeda-beda karena dipengaruhi oleh nilai ekspor ISIC 3 digit setiap tahunnya. Perhitungan PCI menggunakan data perdagangan internasional, khususnya data ekspor produk ISIC 3 digit per provinsi. Semakin besar nilai $\mathrm{PCl}$ berarti produk yang termasuk dalam golongan ISIC 3 digit tersebut semakin kompleks. Berdasarkan perhitungan kompleksitas produk pada langkah diatas, Gambar 1 menunjukkan bahwa kompleksitas produk berkorelasi positif terhadap produktivitas perusahaan pada tahun 2010-2012 dan 2014, sedangkan pada tahun 2013 menunjukkan korelasi negatif.

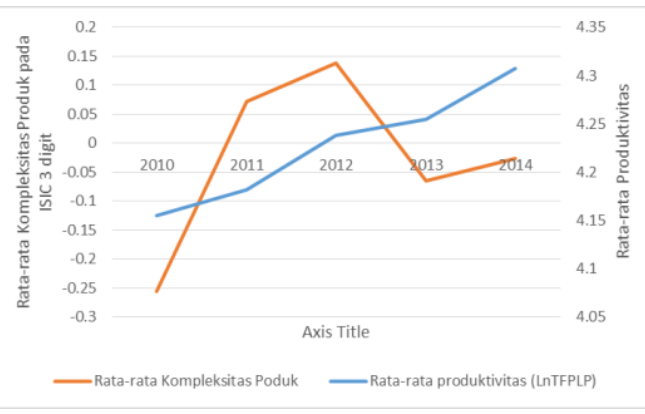

Gambar 1. Kompleksitas Produk dan Produktivitas Perusahaan 2010-2014

Variasi kompleksitas produk juga dapat dilihat berdasarkan kategori kepemilikan perusahaan dan penggolongan teknologi yang digunakan oleh perusahaan. Perusahaan dengan saham asing minimal 20 persen memiliki rata-rata $\mathrm{PCl}$ sebesar 0.144637 , sedangkan rata-rata $\mathrm{PCl}$ bagi perusahaan kepemilikan asing dibawah 20 persen sebesar 0.0669712. Sehingga dapat dikatakan perusahaan dengan saham asing minimal 20 persen menghasilkan produk yang lebih kompleks.

Perusahaan dengan saham pemerintah pusat minimal 51 persen memiliki rata-rata $\mathrm{PCl}$ sebesar 0.0353639 . Sedangkan perusahaan dengan saham pemerintah pusat dibawah 51 persen memiliki rata-rata $\mathrm{PCl}$ sebesar 0.0953727. Dapat dikatakan bahwa berdasarkan kepemilikan saham pemerintah pusat, produk yang dihasilkan memiliki kompleksitas yang tidak jauh berbeda. 
Tabel 2. Statistik Deskriptif Produktivitas Perusahaan Tahun 2010-2014

\begin{tabular}{lrrrrr}
\hline \multicolumn{1}{c}{ Variabel } & Observasi & Rata-rata & Std. Dev & Min & \multicolumn{1}{c}{ Max } \\
\hline Produktivitas & 10,418 & 4.491837 & 0.744521 & -8.73795 & 11.72903 \\
Impor Bahan Baku & 10,418 & 15.55114 & 2.567802 & -0.04718 & 24.59326 \\
PCl & 10,359 & 0.094689 & 0.606362 & -2.13243 & 2.215743 \\
Indikator PMA & 10,418 & 0.357554 & 0.479303 & 0 & 1 \\
Indikator BUMN & 10,418 & 0.011423 & 0.106269 & 0 & 1 \\
Indikator DT & 10,418 & 1.778556 & 0.854048 & 1 & 3 \\
\hline
\end{tabular}

Tabel 3. Pengaruh Impor Bahan Baku terhadap Produktvitas Perusahaan

\begin{tabular}{|c|c|c|c|c|}
\hline & $(1)$ & $(2)$ & (3) & (4) \\
\hline Variabel Dependen: $\ln T F P_{i t}^{L P}$ & OLS & OLS & OLS & FE \\
\hline Impor Bahan Baku & $\begin{array}{l}0.0487^{\star \star \star} \\
(0.0028)\end{array}$ & $\begin{array}{l}0.0351^{* * *} \\
(0.0029)\end{array}$ & $\begin{array}{l}-0.0406^{* * *} \\
(0.0052)\end{array}$ & $\begin{array}{l}-0.0443^{\text {t*t }} \\
(0.0052)\end{array}$ \\
\hline PMA & & $\begin{array}{c}0.121^{* * *} \\
(0.0155)\end{array}$ & $\begin{array}{l}-0.0598 \\
(0.0399)\end{array}$ & $\begin{array}{l}-0.0609 \\
(0.0397)\end{array}$ \\
\hline BUMN & & $\begin{array}{l}0.460^{* * *} \\
(0.0670)\end{array}$ & $\begin{array}{c}-0.229 \\
(0.1720)\end{array}$ & $\begin{array}{c}-0.23 \\
(0.1710)\end{array}$ \\
\hline Dummy Teknologi & & $\begin{array}{l}0.130^{* * *} \\
(0.0084)\end{array}$ & $\begin{array}{l}-0.0241 \\
(0.0247)\end{array}$ & $\begin{array}{l}-0.0263 \\
(0.0246)\end{array}$ \\
\hline $\begin{array}{l}\text { Firm-specific FE } \\
\text { Year-specific FE }\end{array}$ & $\begin{array}{l}\text { No } \\
\text { No }\end{array}$ & $\begin{array}{l}\text { No } \\
\text { No }\end{array}$ & $\begin{array}{l}\text { Yes } \\
\text { No }\end{array}$ & $\begin{array}{l}\text { Yes } \\
\text { Yes }\end{array}$ \\
\hline cons & $\begin{array}{l}3.734^{* * *} \\
(0.0441)\end{array}$ & $\begin{array}{l}3.666^{* * *} \\
(0.0450)\end{array}$ & $\begin{array}{l}5.190^{* * *} \\
(0.0925)\end{array}$ & $\begin{array}{l}5.176^{* * *} \\
(0.0921)\end{array}$ \\
\hline$N$ & 10,418 & 10,418 & 10,418 & 10,418 \\
\hline$R^{2}$ & 0.028 & 0.062 & 0.009 & 0.026 \\
\hline
\end{tabular}

Keterangan:

Variabel Impor Bahan Baku dinyatakan dalam bentuk logaritma natural.

Angka dalam kurung menunjukkan standard error.

${ }^{*},{ }^{* *}$, dan ${ }^{* * *}$ menunjukkan signifikansi masing-masing sebesar $10 \%, 5 \%$ dan $1 \%$.

Berdasarkan teknologi perusahaan, rata-rata $\mathrm{PCl}$ yang dihasilkan sesuai dengan kecanggihan teknologi yang dimiliki perusahaan. Perusahaan yang termasuk kategori teknologi tinggimenengah memiliki rata-rata $\mathrm{PCl}$ terbesar yaitu 0.1891088 . Perusahaan yang termasuk kategori teknologi menengah memiliki rata-rata $\mathrm{PCl}$ sebesar 0.0780053 . Perusahaan yang termasuk kategori teknologi rendah, yang mendominasi sampel penelitian ini, memiliki rata-rata $\mathrm{PCl}$ sebesar 0.0496654. Sehingga dapat dikatakan perusahaan dengan kategori teknologi tinggimenengah menghasilkan produk yang lebih kompleks dibandingkan kategori teknologi lainnya. Statistik deskriptif untuk variabel utama pada regresi yang melihat pengaruh impor bahan baku dan kompleksitas produk terhadap produktivitas perusahaan dapat dilihat pada $\underline{\text { Tabel }}$ $\underline{2 .}$

Regresi dasar untuk melihat pengaruh impor bahan baku terhadap produktivitas perusahaan dapat dilihat pada Tabel 3. Model (1) menyajikan hasil regresi yang hanya memasukkan impor bahan baku sebagai regressor, tanpa mengendalikan efek tetap spesifik perusahaan dan spesifik tahun. Hasil regresi menunjukkan impor bahan baku mempengaruhi produktivitas perusahaan secara positif dan signifikan secara statistik. Peningkatan nilai impor bahan baku sebesar 1 persen akan meningkatkan produktivitas perusahaan sebesar 0.0487 persen. $\mathrm{Hal}$ ini konsisten dengan hasil penelitian sebelumnya yaitu input asing yang berkualitas lebih tinggi dapat meningkatkan produktivitas dengan mengekstraksi teknologi dalam impor input antara.

Selanjutnya pada model (2) ditambahkan regressor jenis kepemilikan perusahaan asing $\geq$ 20 persen, kepemilikan modal pemerintah pusat $\geq$ 50 persen dan penggolongan teknologi yang digunakan perusahaan. Hasil regresi masih menunjukkan impor bahan baku dapat mendorong produktivitas perusahaan sebagai akibat dari limpahan teknologi internasional. 
Peningkatan nilai impor bahan baku sebesar 1 persen akan meningkatkan produktivitas perusahaan sebesar 0.0351 persen. Variabel kontrol yang dilibatkan pada model (2) juga menunjukkan korelasi signifikan secara statistik. Terdapat perbedaan produktivitas perusahaan dengan kepemilikan perusahaan asing $\geq 20$ persen sebesar 0.121 , kepemilikan modal pemerintah pusat $\geq 51$ persen sebesar 0.46 dan perusahaan dengan teknologi tinggi-menengah sebesar 0.130 .

Model (3) mengambil satu langkah lebih maju dengan mengendalikan efek tetap spesifik perusahaan sedangkan model (4) mengendalikan efek tetap spesifik perusahaan dan spesifik tahun. Hasil regresi pada model (4) mengkonfirmasi hasil model (3) yaitu impor bahan baku berpengaruh secara negatif dan berkorelasi signifikan terhadap produktivitas perusahaan.

Berdasarkan hasil regresi model (3) dan (4), dapat dikatakan peningkatan nilai impor bahan baku sebesar 1 persen akan menurunkan produktivitas perusahaan sebesar 0.0351 persen dan 0.0443 persen. Sedangkan hasil regresi untuk ketiga variabel control baik pada model (3) maupun model (4) menunjukkan pengaruh secara negatif dan tidak berkorelasi secara signifikan. Sedangkan dari pengaruh waktu (year specific fixed effect), hasil regresi pada model (4) menunjukkan impor berpengaruh negatif dan signifikan terhadap produktivitas perusahaan. Hal ini dapat dipengaruhi oleh peningkatan hambatan non tarif untuk impor bahan baku yang terjadi pada tahun 2010-2014. Pengaruh positif impor bahan baku terhadap produktivitas perusahaan secara signifikan hanya dihasilkan oleh empat industri yaitu industri minuman (11), pengolahan tembakau (12), industry bahan kimia dan barang dari bahan kimia (20) dan industri karet, barang dari karet dan plastik (22). Berdasarkan uraian diatas maka model (4) terpilih sebagai model terbaik karena telah melibatkan fixed-effect perusahaan $(\bar{\omega})$, fixed-effect untuk waktu t $(\eta t)$ dan variabel kontrol. Hasil pengujian goodness of fit pada model (4) juga menunjukkan nilai R2 yang lebih besar dibandingkan model (3) sehingga dapat dikatakan model (4) mampu menjelaskan data yang ada.

Selanjutnya, untuk mengkonfirmasi pengaruh kompleksitas produk yang dihasilkan oleh perusahaan pada ISIC 3 digit terhadap produktivitas perusahaan, maka dilakukan tahap regresi dengan hasil pada Tabel 4. Model (1) menyajikan hasil regresi yang hanya memasukkan impor bahan baku, indeks kompleksitas produk $(\mathrm{PCl})$ dan variabel kontrol sebagai regressor, tanpa mengendalikan efek tetap spesifik perusahaan dan spesifik tahun.

Hasil menunjukkan impor bahan baku pada produktivitas perusahaan yang menghasilkan barang kompleks (ditunjukkan oleh variabel IBB $x$ $\mathrm{PCl}$ ) memiliki pengaruh negatif dan tidak signifikan. Dengan demikian, pengaruh impor bahan baku terhadap produktivitas perusahaan hanya dapat dilihat dari nilai variabel IBB. Kenaikan nilai impor bahan baku sebesar 1 persen akan meningkatkan produktivitas perusahaan sebesar 0.0355 persen. Hasil ini sesuai dengan hasil penelitian terdahulu yaitu impor bahan baku mempengaruhi produktivitas perusahaan secara positif dan signifikan.

Berdasarkan teori yang telah disampaikan di Bab 2, kompleksitas produk berpengaruh pada proses produksi dan menyebabkan penurunan produktivitas. Akan tetapi hasil model (1) menunjukkan kompleksitas produk tidak berpengaruh secara signifikan terhadap produktivitas perusahaan. Perusahaan yang menghasilkan baik produk kompleks maupun sederhana memiliki pengaruh yang tidak berbeda terhadap produktivitas perusahaan. Variabel kontrol yang dilibatkan menunjukkan korelasi signifikan secara statistik. Terdapat perbedaan produktivitas yang berpengaruh secara signifikan pada perusahaan dengan kepemilikan perusahaan asing $\geq 20$ persen sebesar 0.125 , kepemilikan modal pemerintah pusat $\geq 51$ persen sebesar 0.453 dan perusahaan dengan teknologi tinggi-menengah sebesar 0.134 .

Tabel 4. Pengaruh Impor Bahan Baku dan Kompleksitas Produk terhadap Produktvitas Perusahaan

\begin{tabular}{lccccc}
\hline & $(1)$ & $(2)$ & $(3)$ & $(4)$ & $(5)$ \\
$\operatorname{lnTFP} P_{i t}^{L P}$ & OLS & $\mathrm{FE}$ & Lag-1 & Lag-1,2 & Lag-1,2,3 \\
\hline Impor Bahan Baku & $0.0355^{* * *}$ & $-0.0440^{* * *}$ & $-0.0395^{* * *}$ & $-0.0390^{* * *}$ & $-0.0383^{* * *}$ \\
& $(0.00291)$ & $(0.00523)$ & $(0.00532)$ & $(0.00534)$ & $(0.0054)$ \\
PCI & -0.00686 & 0.0654 & 0.0811 & 0.11 & 0.11 \\
& $(0.0716)$ & $(0.0611)$ & $(0.0613)$ & $(0.065)$ & $(0.065)$ \\
IBB $\times$ PCI & -0.00342 & -0.00495 & -0.00623 & -0.00793 & -0.00788
\end{tabular}




\begin{tabular}{|c|c|c|c|c|c|}
\hline & (1) & (2) & (3) & (4) & (5) \\
\hline \multirow{2}{*}{$\ln T F P_{i t}^{L P}$} & OLS & FE & Lag-1 & Lag-1,2 & Lag-1,2,3 \\
\hline & $(0.00456)$ & $(0.00383)$ & $(0.00384)$ & $(0.00406)$ & $(0.00407)$ \\
\hline \multirow[t]{2}{*}{$\mathrm{PCl}_{\mathrm{t}-1}$} & & & $0.357^{* \star \star}$ & $0.329^{\star \star \star}$ & $0.353^{* \star \star}$ \\
\hline & & & $(0.089)$ & $(0.0915)$ & $(0.0945)$ \\
\hline \multirow[t]{2}{*}{$\mathrm{IBB} \times \mathrm{PCl}_{\mathrm{t}-1}$} & & & $-0.0241^{\star \star \star}$ & $-0.0225^{\star \star \star}$ & $-0.0237^{\star \star \star}$ \\
\hline & & & $(0.00558)$ & $(0.00573)$ & $(0.00585)$ \\
\hline \multirow[t]{2}{*}{$\mathrm{PCl}_{\mathrm{t}-2}$} & & & & 0.0924 & 0.0994 \\
\hline & & & & $(0.0723)$ & $(0.0733)$ \\
\hline \multirow[t]{2}{*}{$\mathrm{IBB} \times \mathrm{PCl}_{\mathrm{t}-2}$} & & & & -0.00544 & -0.00576 \\
\hline & & & & $(0.00458)$ & $(0.00465)$ \\
\hline \multirow{2}{*}{$\mathrm{PCl}_{\mathrm{t}-3}$} & & & & & 0.0489 \\
\hline & & & & & $(0.0682)$ \\
\hline \multirow[t]{2}{*}{$\mathrm{IBB} \times \mathrm{PCI}_{\mathrm{t}-3}$} & & & & & -0.00251 \\
\hline & & & & & $(0.00429)$ \\
\hline \multirow[t]{2}{*}{ PMA } & $0.125^{\star \star \star}$ & -0.0734 & -0.0747 & -0.0751 & -0.0757 \\
\hline & $(0.0156)$ & $(0.04)$ & $(0.04)$ & $(0.04)$ & $(0.04)$ \\
\hline \multirow[t]{2}{*}{ BUMN } & $0.453^{\star \star \star}$ & -0.228 & -0.219 & -0.217 & -0.214 \\
\hline & $(0.0673)$ & $(0.171)$ & $(0.17)$ & $(0.171)$ & $(0.171)$ \\
\hline \multirow[t]{2}{*}{ DT } & $0.134^{* \star \star}$ & -0.0353 & -0.0365 & -0.0367 & -0.037 \\
\hline & $(0.00848)$ & $(0.025)$ & $(0.025)$ & $(0.025)$ & $(0.025)$ \\
\hline \multirow[t]{2}{*}{ 2010.tahun } & & 0 & 0 & 0 & 0 \\
\hline & & $()$. & $()$. & $()$. & $()$. \\
\hline \multirow[t]{2}{*}{ 2011.tahun } & & 0.0177 & 0.0245 & 0.0219 & 0.0229 \\
\hline & & $(0.0159)$ & $(0.016)$ & $(0.0163)$ & $(0.0164)$ \\
\hline \multirow[t]{2}{*}{ 2012.tahun } & & $0.0774^{* * *}$ & $0.0809^{* * *}$ & $0.0805^{\star * \star}$ & $0.0789^{* \star *}$ \\
\hline & & $(0.0164)$ & $(0.0164)$ & $(0.0166)$ & $(0.0167)$ \\
\hline \multirow[t]{2}{*}{ 2013.tahun } & & $0.121^{\star \star \star}$ & $0.124^{\star \star \star}$ & $0.123^{\star \star \star}$ & $0.122^{* * * t}$ \\
\hline & & $(0.0166)$ & $(0.0167)$ & $(0.0169)$ & $(0.017)$ \\
\hline \multirow[t]{2}{*}{ 2014.tahun } & & $0.148^{\star \star \star}$ & $0.149^{\star \star \star}$ & $0.148^{\star \star \star}$ & $0.146^{*+*}$ \\
\hline & & $(0.0173)$ & $(0.0173)$ & $(0.0175)$ & $(0.0176)$ \\
\hline Firm-specific FE & No & Yes & Yes & Yes & Yes \\
\hline Year-specific FE & No & Yes & Yes & Yes & Yes \\
\hline \multirow[t]{2}{*}{ cons } & $3.659^{* \star \star}$ & $5.195^{\star \star \star}$ & $5.132^{\star \star \star}$ & $5.123^{\star \star \star}$ & $5.112^{* * *}$ \\
\hline & $(0.0453)$ & $(0.0929)$ & $(0.0941)$ & $(0.0943)$ & $(0.0952)$ \\
\hline$N$ & 10,359 & 10,359 & 10,359 & 10,359 & 10,359 \\
\hline$R^{2}$ & 0.065 & 0.026 & 0.029 & 0.029 & 0.029 \\
\hline
\end{tabular}

Keterangan: Variabel Impor Bahan Baku dalam bentuk logaritma natural. Angka dalam kurung: standard error. ${ }^{*},{ }^{* *}$, dan ${ }^{* * *}$ menunjukkan signifikansi masing-masing sebesar $10 \%, 5 \%$ dan $1 \%$.

Model (2) menyajikan hasil regresi dengan mengendalikan efek tetap spesifik perusahaan dan spesifik tahun. Hasil regresi model (2) menunjukkan hasil yang berlawanan dengan model (1) yaitu impor bahan baku berpengaruh secara negatif dan berkorelasi signifikan terhadap produktivitas perusahaan. Kompleksitas produk serta interaksi variabel IBB $\times$ PCI menunjukkan hasil yang serupa dengan model (1) yaitu tidak memiliki pengaruh yang signifikan terhadap produktivitas perusahaan. Dengan demikian, pengaruh impor bahan baku terhadap produktivitas perusahaan hanya dapat dilihat dari nilai variabel IBB. Kenaikan nilai impor bahan baku sebesar 1 persen akan menurunkan produktivitas perusahaan sebesar 0.044 persen. Hal ini menunjukkan karakteristik perusahaan dan tahun observasi sangat mempengaruhi produktivitas perusahaan.

Pengaruh positif impor bahan baku terhadap produktivitas perusahaan secara signifikan dihasilkan oleh perusahaan pada industri bahan kimia dan barang dari bahan kimia (20) sebesar $0.0526+0.0327(\mathrm{PCl})$. Dengan rata-rata $\mathrm{PCl}$ sebesar 0.094689 (Tabel 3) maka pengaruh impor bahan baku terhadap produktivitas perusahaan sebesar 0.05569 . Variabel kontrol yang dilibatkan 
juga menunjukkan korlasi negatif dan tidak signifikan secara statistik. Selain itu, dapat dilihat bahwa tahun observasi 2012-2014 berpengaruh positif dan signikan terhadap produktivitas perusahaan.

Produk dengan tingkat kompleksitas semakin tinggi berarti semakin banyak tahapan pada proses produksi sehingga tingkat kesulitan meningkat dan memerlukan lebih banyak pengetahun dalam melakukan setiap tahapan produksi. Hal ini menyebabkan peningkatan kompleksitas produk memerlukan persiapan waktu (masa persiapan) dan menyebabkan terjadinya lag. Model (3), (4) dan (5) menyajikan hasil regresi dengan mengendalikan efek tetap spesifik perusahaan, spesifik tahun serta lag kompleksitas produk (PCl). Regresi menunjukkan hasil yang robust dari ketiga kolom tersebut. Kompleksitas produk yang mempengaruhi produktivitas perusahaan secara signifikan diperoleh dengan menggunakan $\mathrm{Lag} \mathrm{PCl}_{\mathrm{t}-1}$, sedangkan kompleksitas produk di tahun t dan t-3 tidak berpengaruh secara signifikan. Hal ini menunjukkan teknologi atau kecanggihan yang melekat pada produk di waktu $\mathrm{t}-1$, baru berdampak secara signifikan di waktu t. Kompleksitas produk memerlukan waktu selama satu tahun untuk meningkatkan produktivitas perusahaan.

Hasil pengujian goodness of fit pada model (2)-(5) menunjukkan nilai $R^{2}$ yang sama sehingga dapat dikatakan keempat model ini mampu menjelaskan data yang ada. Berdasarkan uraian diatas maka model (5) terpilih sebagai model terbaik karena telah melibatkan lag kompleksitas produk (PCI) selama 3 tahun, fixed-effect perusahaan $\left(\bar{\omega}_{i}\right)$, fixed-effect untuk waktu $t\left(\eta_{t}\right)$ dan variabel kontrol. Peningkatan impor bahan baku pada produk kompleks mempengaruhi produktivitas perusahaan secara negatif dan signifikan. Untuk kenaikan impor bahan baku pada produk kompleks sebesar 1 persen akan berpengaruh terhadap produktivitas perusahaan sebesar 0.0383-0.0237( $\mathrm{PCl})$. Dengan rata-rata $\mathrm{PCl}$ sebesar 0.094689 (Tabel 3) maka pengaruh impor bahan baku terhadap produktivitas perusahaan sebesar -0.040544 persen. Serupa dengan hasil pada model (2), variabel kontrol yang dilibatkan menunjukkan korelasi negatif dan tidak signifikan secara statistik. Selain itu, tahun observasi pada regresi kolom (3), (4) dan (5) berpengaruh secara positif dan signikan terhadap produktivitas perusahaan, untuk tahun 2012-2014.

\section{KESIMPULAN}

Penelitian ini mengeksplorasi hubungan antara impor bahan baku, produktivitas perusahaan dan kompleksitas produk. Hasil empiris menujukkan impor bahan baku industri besar dan sedang di Indonesia tahun 2010-2014 berpengaruh secara negatif dan berkorelasi signifikan terhadap produktivitas perusahaan. Semakin banyak perusahaan mengimpor bahan baku maka produktivitas perusahaan semakin menurun. Hal ini dapat terjadi karena karakteristik masingmasing perusahaan pada ISIC 2 digit memiliki pola impor bahan baku yang bervariasi. Hanya sembilan (9) industri ISIC 2 digit yang mengimpor bahan baku secara konsisten dan bernilai besar dari total dua puluh empat (24) industri ISIC 2 digit. Sembilan industri tersebut adalaha industri makanan (10); tekstil (13); pakaian jadi (14); bahan kimia dan barang dari bahan kimia (20); karet, barang dari karet dan plastik (22); logam dasar (24); komputer, barang elektronik dan optik (26); peralatan listrik (27); serta industri kendaraan bermotor, trailer dan semi trailer (29). Impor bahan baku yang tidak dilakukan secara konsisten dapat meningkatkan biaya input produksi, kemudian mengurangi margin keuntungan, sehingga berdampak pada penurunan produktivitas perusahaan.

Selanjutnya, penelitian ini menunjukkan bahwa pengaruh impor bahan baku terhadap produktivitas perusahaan yang menghasilkan produk kompleks adalah negatif dan signifikan. Dengan menghitung kompleksitas produk pada masing-masing industri ISIC 3 digit maka dapat diketahui produk sederhana mendapatkan manfaat peningkatan produktivitas lebih besar dibandingkan produk kompleks. Hal ini dapat terjadi karena manfaat learning effect produk sederhana lebih besar. Perusahaan yang menghasilkan produk sederhana tidak membutuhkan teknologi spesifik, sedangkan produk kompleks membutuhkan lebih banyak kemampuan untuk mengadopsi teknologi.

Rata-rata kompleksitas produk yang dihasilkan oleh industri manufaktur di Indonesia masih berada pada penggolongan produk sederhana, sehingga peningkatan kompleksitas produk masih berpengaruh signifikan terhadap peningkatan produktivitas perusahaan. Lima industri ISIC 2 digit di Indonesia yang termasuk penghasil produk kompleks adalah industri komputer, barang elektronik dan optik (26); industri pencetakan dan reproduksi media rekaman (18); industri mesin dan perlengkapan ytdl (28); industri peralatan 
listrik (27); dan industri pakaian jadi (14). Sedangkan lima industri ISIC 2 digit yang termasuk penghasil produk sederhana adalah industri kertas dan barang dari kertas (17); industri makanan (10); industri produk dari batu bara dan pengilangan minyak bumi (19); industri pengolahan tembakau (12); industri kayu, barang dari kayu dan gabus (tidak termasuk furnitur) dan barang anyaman dari bambu, rotan dan sejenisnya (16).

Dengan menggunakan lag kompleksitas produk (lag $\mathrm{PCl}$ ) dapat diketahui teknologi atau kecanggihan yang melekat pada produk di waktu $\mathrm{t}-1$, baru berdampak secara signifikan pada waktu $\mathrm{t}$, sedangkan kecanggihan produk di waktu t-2 dan t-3 tidak berpengaruh secara signifikan. Hal ini menunjukkan industri manufaktur di Indonesia memerlukan waktu kira-kira satu tahun untuk menyerap teknologi pada produk kompleks sehingga dapat meningkatkan produktivitas perusahaan.

Selain itu, hasil empiris juga menunjukkan tidak ada pengaruh signifikan dari variabel kontrol terhadap produktivitas. Perusahaan dengan kepemilikan saham asing $\geq 20$ persen, kepemilikan modal pemerintah pusat $\geq 51$ persen dan perusahaan dengan teknologi tinggimenengah tidak mempengaruhi produktivitas perusahaan. Tahun observasi 2012-2014 pada penelitian ini berpengaruh positif dan signikan terhadap produktivitas perusahaan. Hal ini dapat dipengaruhi oleh regulasi impor bahan baku tahun 2012-2014 yang memberikan pengaruh positif terhadap produktivitas perusahaan

Beberapa keterbatasan dalam penelitian ini adalah measuremet biass pada perhitungan Product Complexity Index (PCl) yang menggunakan data ekspor berdasarkan pelabuhan provinsi muat. Eksportir di suatu provinsi menurut data ini belum tentu perusahaan yang menghasilkan produk tersebut. Beberapa faktor penyebabnya adalah infrastruktur atau alat angkutan yang kurang memadai di pelabuhan provinsi asal, jarak tempuh yang lebih dekat dengan pelabuhan provinsi muat serta kapasitas pengiriman yang lebih besar di pelabuhan provinsi muat. Keterbatasan ini berdampak pada setiap langkah perhitungan $\mathrm{PCl}$. Selain itu, keterbatasan lainnya adalah penelitian ini belum mengakomodir kemungkinan terjadinya hubungan timbal balik (kausalitas) antara impor bahan baku dan produktivitas perusahaan.

\section{DAFTAR PUSTAKA}

[1] G. M Grossman and E Helpman, "Quality Ladders in the Theory of Growth," Review of Economic Studies, 1991, Available at : doi $10.2307 / 2298044$.

[2] C. Altomonte and G. Bekes, "Trade Complexity and Productivity," 2009, Available at : doi 10.2139/ssrn.1463198.

[3] H. Kasahara and J. Rodrigue, "Does the use of imported intermediates increase productivity?," pp. 106-118, 2008, Available at : doi 10.1016/j.jdeveco.2007.12.008.

[4] McKinsey. (2002) How IT enables productivity growth: The US experience across three sectors in the 1990s. [Online]. Avaiable at https://www.mckinsey.com/ /media/McKins ey/Business Functions/McKinsey Digital/Our Insights/How IT enables productivity growth/MGI_How_IT_enables_productivity _report.ashx

[5] Robert Z. Lawrence and David E. Weinstein, "Trade and Growth: Import Led ord Export Led? Evidence from Japan and Korea," 1999, Available at : doi 10.3386/w7264.

[6] lacovone Leonardo, Keller Wolfgang, and Rauch Ferdinand. (2011) Innovation Responses to Import Competition. [Online]. Available https://www.semanticscholar.org/paper/Inn ovation-Responses-to-Import-CompetitionAND-lacovone-

Keller/45b126b9aed5f5566949c0414d5879 a519def1ea

[7] D. H. Autor, D. Dorn, G. H. Hanson, G. Pisano, and P. Shu, "Foreign Competition and Domestic Innovation: Evidence from U.S. Patents," NBER Working Paper no. 22879, 2017, Available at : doi 10.3386/w22879.

[8] R. Xu and K. Gong, "Does Import Competition Induce R\&D Reallocation? Evidence from the U.S.," IMF Working Paper no. 17/253, 2017, Available at : doi 10.2139/ssrn.3013441.

[9] Van J. Biesenrbroeck, "Revisiting some productivity debates," Working paper. University of Toronto, 2003, Available at : doi 10.3386/w10065. 
[10] Marc Andreas Muendler, "Trade, Technology and Productivity: A Study of Brazilian Manufactures, 1986-1998," 2004, Available at http://www.cesifo.de/ DocCIDL/1148.pdf.

[11] L. Edwards and Jenkins R., "The Impact of Chinese Import Penetration on the South African Manufacturing Sector," Southern Africa Labour and Development Research Unit Working Paper Series, 2013, Available at : doi 10.1080/00220388.2014.983912.

[12] A. Vogel and J. Wagner, "Robust estimates of exporter productivity premia in German business services enterprises," Economic \& Business Review, 2011. [Online]. https://www.researchgate.net/publication/2 41761638 Robust Estimates of Exporter Productivity Premia in German Busines s Services Enterprises

[13] H. Kasahara and B. Lapham, "Productivity and the decision to import and export: Theory and evidence," Journal of International Economics, vol. 89, pp. 297316, 2013, Available at : doi 10.1016/j.jinteco.2012.08.005.

[14] Michael Kremer, "The O-ring Theory of Economics Development," Quarterly Journal of Economics, pp. 551-578, 1993, Available at : doi 10.2307/2118400.

[15] B. Bayus and W. Putsia, "Product Proliferation: An Empirical Analysis of Product Line Determinants and Market Outcomes," 1999, Available at : doi 10.1287/mksc.18.2.137.

[16] J.A. Quelch and D. Kenny, "Extend Profits, not Product Lines," 1995, Available at : doi 10.1016/0024-6301(95)92184-2.

[17] G.Da Silveira, "A Framework for the Management of Product Variety," 1998, Available at : doi 10.1108/01443579810196471.

[18] T. Stäblien, M. Holweg, and J. Miemczyk, "Theoretical Versus Actual Product Variety: How Much Customisation do Customers Really Demand," 2011, Available at : doi 10.1108/01443571111111955.

[19] M. Mocker and J.W. Ross. (2017) The Problem with Product Proliferation. [Online]. Available at : https://hbr.org/2017/05/theproblem-with-product-proliferation
[20] M.L. Fisher and C.D. Ittner, "The Impact of Product Variety on Automobile Assembly Operations: Empirical Evidence and Simulation Analysis," 1999, Available at : doi 10.1287/mnsc.45.6.771.

[21] C.D. Ittner and J.P. MacDuffie, , "Explaining Plant-Level Differences in Manufacturing Overhead: Structural and Cost Drivers in the World Auto Industry," 2009, Available at : doi 10.1111/j.1937-5956.1995.tb00297.x.

[22] J.P. MacDuffie, K. Sethuraman, and M.L. Fisher, "Product Variety and Manufacturing Performance: Evidence from the International Automotive Assembly Plant Study," 1996, Available at : doi 10.1287/mnsc.42.3.350.

[23] S.A. Wilson and A., Perumal,.: McGrawHill Education, 2009, Available at : doi https://books.google.co.id/books/about/Wa ging_War_on_Complexity_Costs_Reshape Y.html? $i \bar{d}=j 6 \mathrm{v}-\mathrm{u}$ _V1UIIC\&redir_esc $=y$.

[24] W.L. Berry and M.C. Cooper, "Manufacturing Flexibility: Methods for Measuring the Impact of Product Variety on Performance in Process Industries," 1999, Available at : doi 10.1016/S02726963(98)00033-3.

[25] Miaojie $\mathrm{Yu}$ and Jin Li, "Imported Intermediate Inputs, Firm Productivity and Product Complexity," vol. 65, 2014, Available at : doi 10.1111/jere.12041.

[26] Y.-S. Kim, "A system complexity approach for the integration of product development and production design," 1999, Available at : Google Document.

[27] Jesus Felipe, Utsav Kumar Arnelyn Abdon, and Marife, "Product complexity and economic development," Structural Change and Economic Dynamics, pp. 36-68, 2012, Available at : doi 10.1016/j.strueco.2011.08.003.

[28] Miaojie Yu and Guangliang Ye Baozhi Qu, "Trade Liberalisation, Product Complexity and Productivity Improvement: Evidence from Chinese Firms," The World Economy, pp. 912-934, 2013, Available at : doi 10.1111/twec. 12046 .

[29] James E. Rauch, "Networks Versus Markets in International Trade," vol. 48, pp. 
7-35, 1999, Available at : doi 10.1016/s0022-1996(98)00009-9.

[30] C. Hidalgo, "The dynamics of economic complexity and the product space over a 42 years period," 2009, Available at : https://ideas.repec.org/p/cid/wpfacu/189.ht $\mathrm{ml}$.

[31] Bustos Sebastian and Muhammed Ali Yildirim,. Lebanon, 2017, Available at : http://lcps-

lebanon.org/publications/1486465992intro_and_methodology.pdf.

[32] Cesar A Hidalgo and Ricardo Hausmann, "The building blocks of economic complexity," Proceedings of the National Academy of Sciences of the United, pp. 10570-10575, 2009, Available at : doi 10.1073/pnas.0900943106.

[33] G. S. Olley and A. Pakes, "The dynamics of productivity in the telecommunications equipment industry," pp. 1263-1297, 1996, Available at : doi 10.2307/2171831.

[34] J. Levinshon and A. Petrin, "Estimating Production Functions Using Inputs to Control for Unobservable," Review of Economic Studies, vol. 70, pp. 317-342, 2003, Available at : doi 10.1111/1467$937 \times .00246$

[35] Bela Balassa, "Trade Liberalisation and Revealed Comparative Advantage," The Manchester School, pp. 99-123, 1965, Available at : doi 10.1111/j.14679957.1965.tb00050.x.

[36] Roni Nababan, "Memahami Economic complexity Index (ECI) Bagian I ECI Sebagai Indeks Pembangunan Ekonomi Berbasis Produk," 2013, Available at : http://journal.unpar.ac.id/index.php/JurnalA dministrasiBisnis/article/view/1212.
Biografi Penulis

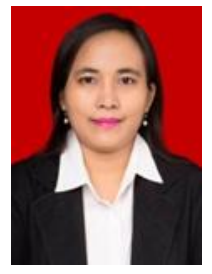

Sirma Oktaviani, S.T, M.S.E., adalah pegawai Direktorat Industri Kimia Hulu Kementerian Perindustrian, yang meraih gelar Sarjana Teknik dari Jurusan Teknik Industri Universitas Katolik Parahyangan Bandung pada tahun 2006, serta meraih gelar Magister Sains Ekonomi dari Program Studi Pascasarjana Ilmu Ekonomi (PPIE) Fakultas Ekonomi dan Bisnis Universitas Indonesia pada tahun 2019. Penulis juga merupakan penerima beasiswa dari Pusbindiklatren Bappenas.

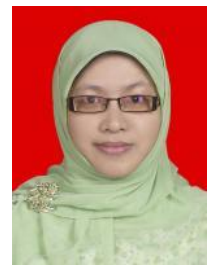

DR. Sartika Djamaluddin, S.E., M.Si, adalah staf pengajar Fakultas Ekonomi dan Bisnis Universitas Indonesia yang memperoleh gelar sarjana ekonomi dari FEUI pada tahun 2000, gelar Magister Ekonomi dari FEUI pada tahun 2004 serta meraih gelar Doktor di bidang Ekonomi Publik pada tahun 2009 di Pasca Sarjana IImu Ekonomi FEUI. Saat ini penulis masih menjadi dosen tamu di program studi Ekonomi Pertahanan dan Program Studi Manajemen Pertahanan di Universitas Pertahanan untuk mata kuliah Ekonomi Publik dan Mikroekonomi dan menjadi narasumber pada Diklat Bank Indonesia untuk mata kuliah matematika ekonomi, ekonometrika dan makroekonomi. 